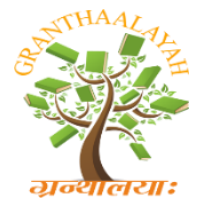

\author{
INTERNATIONAL JOURNAL OF R
GRANTHAALAYAH \\ A knowledge Repository
}

Social

\title{
EXPLORING ESWATINI SENIOR SECONDARY SCHOOL GEOGRAPHY TEACHERS' UNDERSTANDING OF AND ATTITUDES TO EDUCATION FOR SUSTAINABLE DEVELOPMENT
}

\author{
Edmond S. Nkonde ${ }^{1}$, Oloyede O.I. ${ }^{1}$, Peter G ${ }^{1}$ \\ ${ }^{1}$ University of Swaziland
}

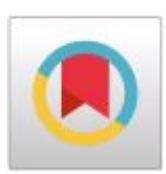

\begin{abstract}
Due to the close affinity that Geography shares with the theoretical constructs and methodologies of Education for sustainable development (ESD), Geography is expected to play a major role in the implementation of ESD. However, for this to take place, Geography teachers ought to have a deep and clear understanding of both sustainable development and ESD and should have positive attitudes towards what these concepts entail. In Swaziland, information about understanding of what both sustainable development and ESD among Geography teachers and what their attitudes are towards these domains of today's world debate is very little. This study is therefore an attempt to fill this gap of information. The study, which was a mixed methods design answered four research questions, had a sample of 92 senior secondary school Geography teachers from 40 systematically sampled schools in the four regions of Eswatini. A self-developed questionnaire which was validated by two experts at the University of Eswatini, with a reliability value of 0.72 was used. Results obtained were analysed using Qualitative content analysis (QCA) method and Statistical Package for Social Scientists Version 10 (SPSS_10) and Excel. The results indicated that Geography teachers lacked a deep and clear understanding of the theoretical constructs of both sustainable development and ESD. More so, very few teachers had any clear, supported understanding of what ESD is all about. Despite this lack of knowledge, teachers showed a high level of positive attitudes towards sustainable development and ESD. The study concluded that a majority of the geography teachers did not understand the concept of ESD and recommended that sustained in service training programmes be put in place urgently and teacher training institutions should fully incorporate ESD in education training programmes to empower trainee teachers who would be the implementers of ESD.
\end{abstract}

Keywords: Sustainable Development; Education for Sustainable Development; Understanding; Teacher Attitudes.

Cite This Article: Edmond S. Nkonde, Oloyede O.I., Peter G. (2019). "EXPLORING ESWATINI SENIOR SECONDARY SCHOOL GEOGRAPHY TEACHERS' UNDERSTANDING OF AND ATTITUDES TO EDUCATION FOR SUSTAINABLE DEVELOPMENT." International Journal of Research - Granthaalayah, 7(10), 407-417. 


\section{Introduction}

As nations seek economic development there has been irrational and competing exploitation of the natural resources the effects of which have been environmental, economic and social challenges. Thus, to live sustainably has been the main challenge that humanity faces today. In turn, this has generated restlessness and concern for the future generations and has propelled scientists, scholars and politicians all over the world to call for the inclusion of topics such as the environment and education in the agendas of international discussions undertaken to protect the environment and address the economic and social developmental challenges brought about as a result of the unrestrained exploitation of the earth's ecosystem on which humanity depends for its survival. The UN sums up the sustainability challenges that we face today. It declares that:

"The world today is faced with more economic, social and environmental challenges than ever before. The world now is more and more experiencing worsening of poverty, hunger, ill health, illiteracy, gender inequalities, Perpetuation of economic disparities between and within nations and the deterioration of the ecosystem on which humanity depends" (UNCED, 1992. P.1).

To tackle such problems raised education is seen as key to bringing about sustainable development. Accordingly, the 1992 Rio De Janaeiro Conference (Agenda 21) termed this kind of education which was to be the means for the attainment of sustainable development goals as education for sustainable development (ESD). Thus, one can argue that the real birth of ESD is inherent in the 1992 Rio De Janeiro Summit. It is this conference which delegated chapter 36 of agenda 21 action plan for sustainable development to education where it is noted that "Education is critical for promoting sustainable development and improving the capacity of the people to address environment and development issues," (UNCED, 1992 :36, p. 3). To this end McKeon (2002) argues that education is a critical tool for achieving social, economic and ecological sustainability. However, ESD did not really take off on a grand scale until 2002, (Polimeni, 2011). In 2002, another UN Summit on sustainable development took place in Johannesburg, South Africa. This Conference revitalized and reinforced support for sustainable development and education for sustainable development.

According to Pavlova (2011), the 2002 Johannesburg conference realized that there was an urgent need to address issues of sustainability through education if any headway was to be made in sustainable development efforts. Consequently, this realization led the UN to declare 2005-2014 a decade of education for sustainable development (DESD) which was launched by UNESCO on 1 March 2005, (UNESCO, 2005). By this declaration, all UN member states were required to develop policies and strategies that would ensure that education at all levels, that is, from preschool to university embraced issues of sustainability, (UNESCO, 2005). What this means is that DESD had the goal of thoroughly and internationally implementing ESD in institutions of learning at all levels (Burmeister \& Eilks, 2013).

It is therefore the 2002 Johannesburg Summit that put in motion the operation of ESD through the declaration of DESD. During the period of DESD, 2005- 2014, the main goal of ESD was to see a world where everyone had the opportunity to benefit from quality education and learn values, behaviours as well as lifestyles required for a sustainable future and for positive societal transformation (DESD,2005). According to UNESCO (2005) Education for sustainable 
development is therefore a kind of education geared at promoting development that is environmentally sound, socially equitable, culturally sensitive and economically just. It also aims at developing the spirit of resilience among the learners and helping them to become responsible and caring citizens and adopt positive change. Furthermore, ESD is geared at promoting a kind of learning that respects the different beliefs and cultures of other people and also create peaceful and sustainable societies. ESD further fosters learning that should be able to bring about understanding of global issues and help in solving local problems with global roots such as HIV and AIDS, global warming and climate change, poverty issues, migration and housing. Inculcation of knowledge, values and skills are also part of ESD regime.

For education to play the role as a tool through which to promote sustainable development, then, teachers become important stake holders, because without them there can hardly be teaching and learning about sustainable development especially in the formal educational setting. This also means that teachers have to implement ESD through their subject disciplines as ESD is not a standalone subject but exists as a domain mainstreamed into the various school subjects like Geography. This further means that teachers need to have a full and clear understanding of what this new approach in education is all about so that they can effectively incorporate it in their lessons.

Many scholars have argued that if education is indeed the solution to working toward a sustainable future as argued by the United Nations (UNCDED, 1992) then teachers are a crucial component (Simo, 2014). But then these teachers, in this case Geography teachers, should be empowered with sufficient and necessary subject and instructional knowledge through teacher training (Firth \& Winter, 2007) if they have to implement ESD through teaching of their subjects. Burmeister \& Eilks (2013) argue that teachers need specific subject matter knowledge (SSMK) to deal with ESD in general and their subject topics in particular. A teacher needs knowledge about sustainable development and also knowledge about basic definitions, concepts and models used in the debate about ESD and sustainable development (Burmeister and Eilks, 2013).

Burmeister and Eilks (2013) further explained that subject matter knowledge alone is not good enough; a teacher also ought to possess different forms of instructional knowledge, if the teacher has to effectively implement ESD because the topics and objectives of ESD driven subject will definitely differ from the traditional practices. Magnusson, Kraijcik and Barko (1999) also contend that for teachers to carry out successful teaching possession of deep knowledge of subject matter and knowledge of appropriate instructional skills is critical.

Applied to Geography, this means that Geography teachers should not only have a full and clear understanding of what both sustainable development and education for sustainable development are, but should also have the necessary pedagogical strategies related to the teaching of Geography. Phiri (2011) also argued that for teachers to properly promote ESD through their respective subjects, they need to have sufficient subject and curriculum knowledge and also the necessary instructional methods required for the teaching of ESD related areas within the Geography curriculum. Furthermore, for successful implementation of sustainable development through education, Haney (1996) argued that teachers should have prior knowledge of subject content and also have positive attitudes, beliefs and opinions on ESD because to a large extent these would influence the way the teachers are likely to teach the different aspects of this concept. For this 
reason, Pajares (1993) believes that any educational innovation is doomed to fail if it does not take into account teacher beliefs, perceptions and attitudes.

When it comes to the Eswatini General Certificate of Secondary Education (EGCSE) Geography syllabus, one would indeed note a lot of evidence of sustainable development issues. Firstly, this evidence is seen in the Eswatini National policy Directives as articulated in the Geography syllabus document, (EGCSE Syllabus 2015-2016, P. 3) (See table 1)

Furthermore, analysis of the EGCSE Geography syllabus, (2015 -2016) reveals that many themes, general and specific objectives or topics are ESD related. The syllabus contains themes such as the physical world, where topics such as weather and climate, global warming and climate change, water resources are dealt with. The other theme is Economic development with topics such as food production, industrial development both in low economically developed countries (LEDCs) and more economically developed countries (MEDCs), transport and mining. The other topics under this theme include leisure activities and sustainable tourism, renewable and non-renewable resources as well as power generation with alternative sources of power being emphasised, Population dynamics, rural and urban settlements. This being the case it would be argued that ESD is fully integrated into the SGCSE Geography curriculum.

From the discussion so far, it is clear that in formal education, Geography should contribute strongly to the promotion of sustainable development. Simo (2014) argues that within the context of formal education, different types of school Geography around the world have been confronted with the challenge of implementing the very ideas of ESD. But as already pointed out, Geography teachers need specific subject matter knowledge related not only to Geography as a subject but to ESD as well. Furthermore, Geography teachers also need to have knowledge of the necessary pedagogical methods and approaches so that they are able to effectively incorporate this new and evolving educational domain in their lessons. But then teaching pedagogies can only be effectively applied if teachers possess sufficient content knowledge of their subjects and have positive attitudes towards what they are tasked to implement, in this case ESD. Hence this study explores Geography teachers understanding of and attitude to ESD.

\section{Objectives of the Study}

The objectives of this study were:

1) To explore the Eswatini senior secondary school Geography teachers' understanding of ESD.

2) To determine the attitudes of the Eswatini senior secondary school Geography teachers' towards ESD.

\section{Research Questions}

The research questions to be answered in this study were:

1) What do the Eswatini senior secondary school Geography teachers' understand about ESD?

2) What are the attitudes of the Eswatini senior secondary school Geography teachers towards ESD 


\section{Literature Review}

\section{Conceptual Framework for understanding sustainable development and ESD}

In establishing the Geography teachers' understanding of ESD the Vane model or Trinity model as it is sometimes called, as proposed by Tremel (2003) was used. The Trinity Model

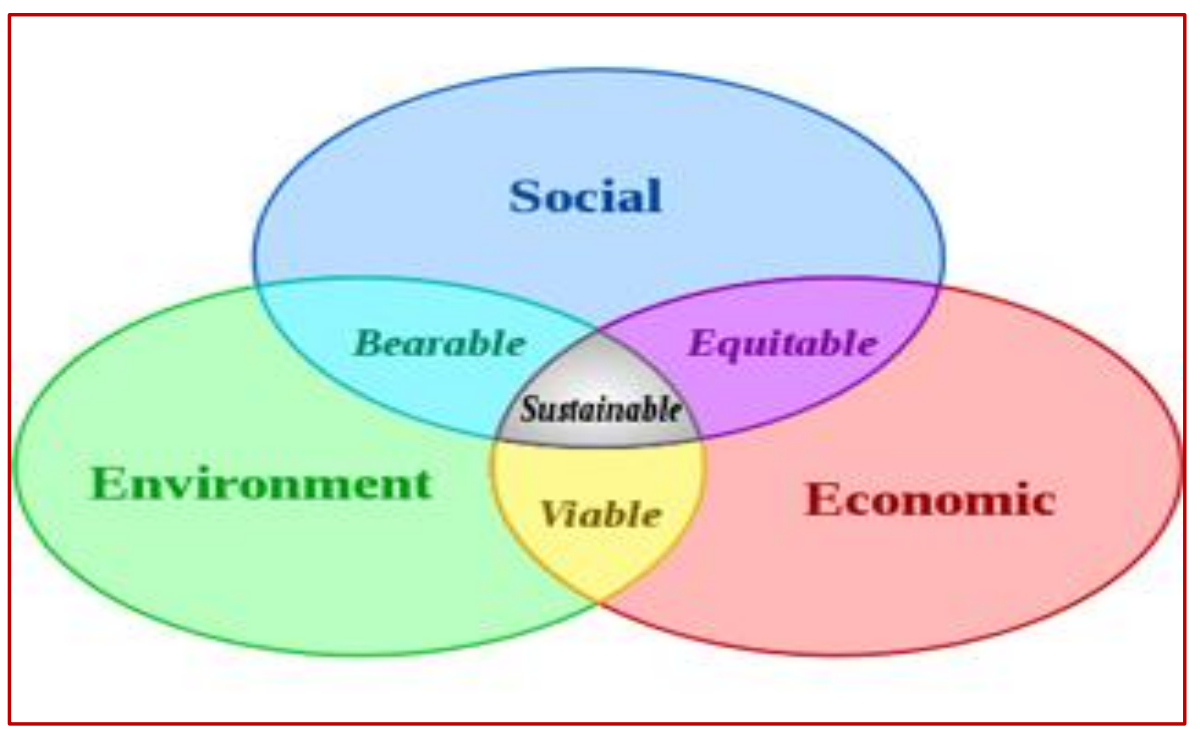

Figure I: Trinity Model by Tremmel (2003) The Three Pillars of Sustainability Source: http://www.thwink.org/sustain/glossary/ThreePillarsOfSustainbility.htm

above illustrates and simplifies the visualization of the constructs of sustainable development. Analysing this model, it is clear that sustainable development is a function of three pillars, environment, economy and society which interact. It is further argued that if these interactions are well managed, social and economic equity will be realised. Furthermore, there will be environmental and economic viability. In the same respect, the social - environmental impacts will also be bearable. Therefore, according to Simo (2014) teachers' full understanding of all the three pillars of sustainable development is critical. Education for sustainable development in this respect is therefore geared at addressing environmental, economic and social sustainability issues. Simo (2014) further argues that unless teachers themselves have positive attitudes, even if they understand sustainable development and ESD constructs very well, they will not implement the demands of ESD effectively as the way they are likely to approach ESD issues will largely be influenced by their beliefs, values, attitudes, and perceptions they hold about ESD.

\section{Empirical Studies}

Rauch and Steiner (2013) confirmed that a lot of research papers on ESD have been published since the 1992 UN Conference on Environment and Development in Rio de Janeiro. Simo (2014) conquers with Rauch and Steiner (2013). He argues that over the past twenty years, ESD has received a lot of attention by educationists, politicians and researchers. In the UK, there have been a notable number of researches analysing specific subject matter knowledge in the fields of Geography, Science and Primary education. Summers et al. (2000) in Burmeister and Eilks (2013) conducted a survey in England to determine the understanding of sustainable development and education for sustainable development among primary and secondary school Science teachers. 
Using a questionnaire, 120 primary school teachers and 88 secondary Science teachers were asked on their understanding of sustainable development and education for sustainable development. After qualitatively and quantitatively analysing the data from the questionnaires the teachers had filled in Summers et al (2000) in Burmeister and Eilks (2013) found that most of the respondents, both serving primary and secondary school science teachers associated sustainable development and education for sustainable development to environmental issues and could not relate clearly the economic and social aspects to sustainable development or ESD. Most notably, most of the teachers did not know what ESD all was about and were not sure of the appropriate pedagogical methods and approaches necessary for the teaching of ESD.

Summers and Childs (2007) also conducted a similar study. They used a sample of 170 practicing teacher trainees in the UK to carry out a survey to determine teachers' perceptions, attitudes and beliefs regarding sustainable development and ESD. After statistically and qualitatively analysing the data they obtained from the questionnaires and structured interviews, the researchers found that a substantial number of the respondents acknowledged the centrality of the three pillars of sustainable development, that is, environment, economy and society. $72 \%$ responded that the Environment was central, 53\% acknowledged the economic aspect while $31 \%$ highlighted the social aspect. But just $15 \%$ acknowledged all the three as being important to sustainable development, (Summers \& Childs, 2007, p.307).

Seybold and Rieb (2006) conducted two studies in Southern Germany, one involving 787 primary school teachers and the other involving 1865 secondary school teachers in their different subjects. Using a survey questionnaire these teachers were asked about their understanding of sustainable development and educational for sustainable development in schools. According to Seybold \& Rieb (2006) both studies reveal that there was lack of specific subject matter knowledge especially in the area of ESD among the teachers. Most evidently, the teachers associated sustainable development and ESD to environmental domain.

Furthermore, Povlova (2009) reports that survey studies done in France, Australia and Russia to determine teachers' perceptions of sustainable development and whether to include sustainability issues in teacher education curriculum or not, yielded the following findings: Most pre-service teachers and practicing teachers in the three countries mentioned who were drawn from both primary and secondary schools were not very familiar with the concept of sustainable development and ESD. However, the exceptions were those teachers who were personally engaged in activities which were relevant to sustainable development outside their teaching work, and also those other group of teachers who had studied environmental sciences at university. This group of teachers demonstrated familiarity and some understanding of sustainable development and education for sustainable development, (Pavlova, 2009).

Another similar study was conducted by Burmeister and Eilks, (2013). The two researchers conducted a study to find out more about German student teachers' and trainee teachers' understanding of sustainability and ESD in the chemistry subject. The study also sought to determine teachers' beliefs and attitudes towards the ideas of sustainable development and ESD. In this study 87 student teachers and 97 trainee teachers answered a set of closed, Likert-type and open survey questions in a questionnaire. The Likert items from the questionnaire were analysed quantitatively while the open type of questions was analysed using qualitative content (QCA) 
method. Burmester and Eilks (2013) found that many of the student and trainee chemistry teachers had positive attitude towards the idea of sustainability and sustainable development. However, very few of the participants were able to base such positive attitude on knowledge about sustainability. Most of the participants understood sustainability and sustainable development as stemming from environmentally related topics. The interplay between ecological, economic and societal issues was rarely mentioned. Similarly, the study showed that most of the participants from both groups lacked any theoretical knowledge about ESD. They were also unsure of any related pedagogies or teaching approaches which may help them in teaching sustainable development in chemistry.

In the case of Swaziland, from the literature accessed by the researcher there is lack of information suggesting or establishing how knowledgeable Geography teachers in Swaziland are in matters pertaining to sustainable development and ESD. This study therefore focuses on establishing understanding of sustainable development and ESD among senior secondary school Geography teachers teaching the SGCSE Geography syllabus.

\section{Methodology}

This study employed a mixed methods research design. 92 senior secondary school Geography teachers systematically sampled from ten schools (five schools from urban and five from rural) from each region, participated in the study. The instrument for the study was a researcher developed questionnaire which had a combination of open, closed and Likert-type questions. The instrument was validated by two experts from the University of Eswatini and has a test - retest reliability value of 0.72 . Data was analysed research question by research question using SPSS version 10, which produced frequency tables which produced coded categories, frequencies and percentages for each category.

\section{Findings and Discussions}

The following were the findings of the study:

\section{Research question 1:}

What is the SGCSE Geography teachers understanding of education for sustainable development?

Results indicated that the majority $(66 \%)$ of the teachers revealed that they had no idea about ESD or a sound understanding of what ESD means. The answers this category of teachers gave were way out of line and most of them just wrote "No idea". Only 5\% of the respondents demonstrated full understanding of ESD. There was also another $15 \%$ who had average understanding of ESD. These teachers expressed at least two areas of sustainability which are a concern for ESD. Those who are described as having little understanding demonstrated at least one idea in the right direction such as 'ESD is concerned with teaching students about the environmental awareness'. However, this answer is far away from any elaborated definition of ESD and does not express the main idea of ESD which deals with students taking personal action for a sustainable future, Burmeister \& Eilks (2013). Worth noting is the fact that some of the teachers viewed ESD as education about saving the world's resources so that we may continue to use them even in the future. This understanding however falls short of holistic perspectives in that it only touches on 
one aspect of ESD. It fails to bring out the interplay among the three pillars of sustainable development which ESD is designed to address, that is, environmental sustainability, economic sustainability and social sustainability.

\section{Sources of knowledge on ESD}

When teachers were asked about their source of knowledge on education for sustainable development the result indicated that the majority obtained it from either mass media (48\%) or from university (46\%). On the other hand, very few obtained it from college (5\%) or from books (1\%). Getting knowledge on this concept from the mass media really means that a full and clear understanding that education for sustainable development is about environmental, economic and social sustainability is really not guaranteed. Usually mass media tends to educate or inform its audiences with a bias towards the needs of the proprietors. The other source of knowledge as indicated is the university (46\%). However, most of these mentioned that they did not get the knowledge from specific Geography courses but from their environmental clubs. This points to the fact that in the Universities in Eswatini ESD is not yet fully integrated into various training programmes although ESD is supposed to be incorporated into curricula at all levels, from preschool to university (DESD, 2005).

\section{Research question 2 \\ What are the attitudes of the SGCSE Geography teachers towards ESD?}

When teachers were asked to indicate how they rated the importance of ESD in relation to Geography, results shows that $75 \%$ of teachers believed that ESD was a very important approach to geography education. Another $20 \%$ who viewed ESD as important, bringing the number of respondents who acknowledged the importance of ESD to $95 \%$. On the other hand, $4 \%$ viewed ESD as less important, with another $1 \%$ indicating that it was not important at all, bringing those with negative attitudes towards ESD to only 5\%. To this end, one would argue that Geography teachers' attitudes toward ESD were very positive. But it must be mentioned once again that very few participants were able to tie such positive attitudes to theory based knowledge on ESD. As seen already in research question $166 \%$ of the participants did not understand what ESD was all about. Yet, these results for research question 2 indicates that the majority (75\%) viewed ESD as very important with $20 \%$ stating that ESD was important. It may be argued that the belief in the importance of ESD to geographical education emanates from the teachers' understanding that ESD is a type of education meant to address issues of the physical environment.

When the relationship between teachers' levels of education and their beliefs in the importance of ESD was investigated, results indicate that $100 \%$ of the teachers with Masters Degrees viewed ESD as a very important approach to Geography education, while $73 \%$ of those with Bachelors Degrees also affirmed the importance of ESD. When the $73 \%$ of those with Bachelor's degrees who said ESD was very important is added to the $21 \%$ of those who indicated that ESD was important, one realizes that $94 \%$ of all the teachers with Bachelor's degrees acknowledged the importance of ESD to Geography education. Only $6 \%$ had negative views about ESD, that is, $1 \%$ indicated that ESD was less important while 5\% stated that it was not important; bringing to $6 \%$ the number of the participants who viewed ESD as not being important. Even when one looks at the teachers with Diploma level of education, results showed that $50 \%$ viewed ESD as very important with $25 \%$ saying it was important, bringing to $75 \%$ the number of Diploma holders who believed in the importance of ESD. Like results on understanding of ESD, these results indicate 
that among the participants, there was a correlation between level of education and attitude towards ESD. This means that the higher the level of education one attained the more positive one was about ESD. However, it is also true $t$ to state that in general participants at all levels of education demonstrated positive values towards ESD.

\section{Discussion of Findings}

The results of this study showed that many of the SGCSE Geography teachers who participated in the study demonstrated lack of knowledge and understanding of ESD. Most of the participants' interpretation of ESD stemmed from environmental related topics. The interplay between ecological, economic and societal dimensions which are the three pillars of sustainable development (Tremmel, 2003) was hardly mentioned. These findings are similar to related studies in other countries. For example, in the UK, Summers, Kruger, Childs \& Mant (2000) investigated the understanding of 12 primary science teachers' understanding of sustainable development and ESD. The study revealed that this group of Primary school teachers had substantial understanding of some aspect of sustainable development, but mainly those associated with ecological domain. However, the economic and social domains were more or less not understood by the teachers.

Summers, Corney and Childs (2004) also examined Science and Geography student teachers. They examined the teachers' perceptions regarding sustainable development. They found that most of the teacher participants recognized the centrality of the environment with regard to sustainable development and ESD. Furthermore, Burmeister \& Eilks (2013) investigated the understanding of sustainability and education for sustainable development among German student teachers and trainee teachers of Chemistry. They found that many of the Chemistry

students` did not have a sound understanding of sustainable development and ESD and yet the students viewed sustainable development and ESD as very important. That is their attitudes towards ESD were very positive. However, their positive attitudes towards ESD were not informed by their theoretical knowledge of ESD. This is encouraging in that how ESD would be implemented will be guided by the positive attitudes of teachers. UNESCO (2005) also stresses that positive attitudes are very important because countries usually approach implementation of education innovations according to the values that have been established due to beliefs, attitudes and norms that a particular society holds.

This study has also established that understating of ESD among the participants was related to level of education. The participants who possessed Masters' Degrees had a better understanding of both sustainable development and ESD followed by those with Bachelors degrees and lastly those with Diplomas. However, despite this comparative difference the study has also affirmed that all in all participants at all levels of education regarded ESD as immensely valuable and therefore had high positive attitudes towards ESD.

\section{Conclusion}

Based on the findings, the study concluded that;

- The majority of the Swaziland senior secondary school Geography teachers teaching the SGCSE programme who participated in the study have poor understanding of ESD. 
- SGCSE Geography teachers who participated in the study showed high positive attitudes towards ESD and there is a correlation between level of education and Geography teachers attitude towards ESD.

\section{Recommendations for Action}

- There is an urgent need for in service training programmes on ESD content for Geography teachers so that they acquire theory-based knowledge of sustainable development and ESD especially because sustainable development related topics have already been mainstreamed in the SGCSE Geography curriculum.

- There is need for higher institutions of learning responsible for the training of teachers to incorporate ESD and sustainability based topics in their training programmes to fully equip Geography trainee teachers with subject matter knowledge and instructional pedagogies so that once they graduate they are ready to implement ESD through teaching of the Geography subject.

\section{References}

[1] Burmeister, M. \& Eilks, I. (2013). Understanding of Sustainability and Education For Sustainable Development among Germany student teachers and trainee teachers of chemistry: Science Education International, Vol. 24 issue 2, 2013, 167-194

[2] Firth, R. \& Winter C, (2007). Constructing Education for Sustainable Development: The Secondary School Geography Curriculum and Initial teacher training, Environmental Educational Research, Vol. 13, No, 5, pp599 - 619, http://.dx.doi.org/10. Accessed 28/1/2016

[3] Government of Swaziland (2011). Education Sector Policy, Mbabane

[4] Haubrich, H. (2000). Sustainable Development in Geography for the $25^{\text {th }}$ Century: International Research in Geographical and Environmental Education, 9,279-284.Doi: 10.1080/10382040008667660

[5] Haubrich,H. Reinfriend, S. \& Schleicher,Y. (2007). Lucerne Declaration on Geographical Education for Sustainable Development, in S. Reinfriend, Y. Schleicher, \& A. Rampfler (Editors), Geographical views for Education for Sustainable Development: Proceedings, (pp. 243-250). Weigarten: HOD

[6] Magnusson, S. Krajcik,J. \& Barko, H. (1999) Nature, Sources, and Development of Pedagogical contentment knowledge for Science teaching. In J, Gess-Newsome \& N.G. Lederman (Editors) Examining Pedagogical Content Knowledge (PP 95-132). Dordrecht: Kluwer.

[7] Manyatsi, D. (2012). Mainstreaming Educational for Sustainable Development in the School Curriculum, University of Swaziland Faculty of Education, Kwaluseni.

[8] Mckeown, R. (2002). Education for sustainable Development Tool Kit, version 2, http://www.esdtoolkit.org, accessed: 9/10/2014

[9] Oloyede, O.I. (2009). Educational Research Methods and Statistics, Kaduna, Euneeks and Associates, Kaduna.

[10] Ondigi, (2012). S.R. Geography and Pedagogical Approaches used for training of Pre service teachers in Kenyan Universities: A case of Kenyatta University International Journal of Academic Research in Progressive Education and Development, Vol. 1 No. 4

[11] Pajares, F. (1993) Pre service teachers' beliefs: A focus for Teacher Education Action In Teacher Education, 15, 45 - 45. http://www.des.emory.edu/pajareis, Accessed

[12] Phiri, K.T. Relevance of ESD to Zambian High School Geography: a survey of Lusaka City Schools, MEd Thesis: Environmental Education, http://dspace.unza.zm. Accessed, 17/8/2014 
[13] Pavlova, M. (2011). Frame work for developing teaching Approaches and Resources for Education for Sustainable Development. http://link,Springer.com/chapter/10.1007/978-1-4020-8194-1-32 accessed: 22/9/2014

[14] Polimeni, C.M. (2011). Geography and sustainable Development in Teaching and Education in Argentina, Springer link.com/chapter 10.10007/978-007-1754-1_5. Acessed: 22/9/2014

[15] Rychen, D.S. \& Salganik. (2003). Education for Sustainable Development Tool Kit, www.esdtoolkit.com; accessed:11/4/15

[16] Rauch, F. \& Steinner, R. (2013). Competencies for Education for Sustainable Development in Teacher Education. CEPS Journal 3 (2013), I,S,9-24, www.Pef.Uni.ij.si, accessed: 4/3/2015

[17] SGCSE Geography Syllabus - 6890 (2015-2016) Examinations Council of Swaziland, Ezulwini

[18] Sollart, K. (2004). Frame work on indicators for Education for Sustainable Development: Some Connectional thoughts motherlands Environmental Assessment Agency, MNP.

[19] Simo, P.S. (2014). Tracing Sustainability: Education for Sustainable Development in the lower Secondary Geography Curriculum of Germany, Romania, and Mexico: International Research in Geographical and Environmental Education, Vol.23, No.2,126-141, http://dx.doi.org/, 10.1080/10382046.2014.908525: accessed: 28/10/2014

[20] Swaziland Population (2016). www.wprldometere. Info>Swaziland. Accessed: 25/9/2016

[21] Tremmel, J. (2003). Sustainability as political and analytical category, Munich, Ekom

[22] UNESCO, (2002). Education for sustainability: from Rio to Johannesburg, lessons learned from a decade of commitment, Paris, UNESCO.

[23] UNESCO, (2005). UN Decade for sustainable Development, 2005-2014: Implementation Scheme: UNESCO Education sector: www.Unesco.org/education/ accessed 17/3/2015.

[24] UNDESD, (2005). Towards the implementation of Decade of Education for Sustainable Development in Sub Saheran Africa, Workshop Report, Windhoek, Namibia.

[25] UNESCO, (2013). Education for sustainable development in the UK - Current status, best practice and opportunities for the future, policy brief 9, London, National Commission for UNESCO.

[26] UNCED, (1992). UN World Summit on Environment and Development, Rio De Jenairo, www.Un.otg/gainfo/bp/enviro.html: accessed 12/08/2014.

[27] WCED, (1987). Our Common Future, London, Oxford Press.

*Corresponding author.

E-mail address: oioloyede@ uniswa.sz 